\title{
'One Does Everything to Make Life Better.' Petty Corruption and Its Legal Implications in Hungary
}

\begin{abstract}
Combining research into the law with the conceptual framework offered by legal anthropology contributes to a more thorough understanding of how individuals experience corruption and anti-corruption legislation. Interviews with elderly Hungarians allow a deeper understanding of traditions and individual behaviour that influence the implementation of anti-corruption law. Informal payments in health care, in the realm of petty or everyday corruption, have become social traditions based on a general faith in their ability to organize and determine social and individual relations. At the same time, they have turned out to be exceptional challenges as far as their legal adjudication is concerned, as individuals are keen to find stability and reliability in norms, traditions and personal relationships outside the scope of the law.
\end{abstract}

Petra Burai is a Research Associate at the Max Planck Institute for Social Anthropology, Halle, Germany.

\section{Introduction}

Corruption is hardly a legal success story in Hungary. While only a small percentage of the relevant cases reach the authorities and even fewer reach the courts, $89 \%$ of Hungarian respondents believe corruption is widespread in the country. ${ }^{1}$ The remarkable gap between the true numbers and public perception represents an opaque area at the boundaries of the law where private motivation and social practice often override the interests of the state. Equally, constant interactions and tensions arising in individual communities, between individuals and the authorities, and between communities and the authorities

${ }^{1} 36 \%$ of the respondents think that corruption in Hungary is 'very widespread' (compared to the European Union (EU) average of 35\%) and 53\% claimed that it is 'fairly widespread' (in the EU: 41\%). Eurobarometer on Corruption, European Commission, 2013, http://korrupciomegelozes.kormany.hu/download/8/49/90000/EUROBAROMETER\%2079_1\%20-\%20 Magyarorsz\%C3\%A1gi\%20eredm\%C3\%A9nyek.pdf. All internet references were accessed on 2 July 2017. 
simultaneously shape and uphold traditions and practices which legal regulation is unable to tackle. ${ }^{2}$

Meanwhile, for many Hungarians corruption is a sensitive, often frightening and highly contradictory topic. General reluctance to talk openly about personal experiences has direct consequences, because research done in the field consists predominantly of quantitative social surveys or legal desk researches. Such studies offer important findings about the 'big picture' of the phenomenon's social and legal attributes. However, the anthropological element of legal paradox is often missed when the relevant laws are adopted and implemented.

This article sets out to examine how and why personal motivations have influenced the implementation of anti-corruption laws, especially criminal sanctions regarding informal payments under the various political regimes in Hungary. The analysis introduces elderly people's experience of health care and their attitudes to the authorities and to legal regulations. The individual stories and opinions of the respondents reflect the social effects of the political, legal, and economic changes that occurred, and throw light not only on an ambivalent view of corruption and the law in Hungary, but also on the reasons for the 'practical impossibility' of adjudicating such cases in any court of law.

In the course of research for this article, ten semi-structured in-depth interviews with elderly Hungarians were carried out between September 2014 and August 2015. All subjects were at least 70 years old and had lived through different political eras. The transformations they had seen had resulted in 'mixed mind-sets' influenced by a number of different ideological systems. Those personal mind-sets have become 'layered ideological systems' co-existing and in constant interaction with each other as daily decisions were made. ${ }^{3}$

The structure of the interviews was predominantly autobiographical, with the focus on first hand witness of corruption or abuse of power in connection with experience of treatment in the health care sector. The analysis of the answers examined the main determinants of the legal adjudication of the giving and taking of informal payments, including personal motivations, the nature of relationships, and the duration and value of exchanges.

The main purpose of the analysis was to try to explain the human and social dimensions of the dysfunction of the law. It should be noted that the study is not based on a statistically balanced sample. Instead, to provide a full picture it relies on grounded theoretical sampling and theoretical saturation moving from

2 Ernő Tárkány-Szűcs, Magyar jogi népszokások, Budapest 1981, 37.

3 György Gajduschek, 'The Opposite is True! ... as Well!' ... If that Is Expected. Extremely Inconsistent Values. Empirical Evidence from and Speculation over Hungarian Survey Data. Keynote speech given at the conference 'Central and Eastern European Socio-Political and Legal Transition Revisited - Theoretical Perspectives', Budapest, 22 April 2016. 
case to case, deciding what data to collect to maximize research opportunities. ${ }^{4}$ Seven of the interviews were done in Eger, Hungary, at the Zellervári Közösségi Ház (Zellervár Community Centre). Eger is the administrative centre of Heves county in northeastern Hungary and is home to approximately 55,000 inhabitants.

\section{Petty Corruption in Its Social Settings}

In the most pragmatic terms corruption might be described as 'decisions made by politicians and public bureaucrats (public officials for ease of exposition) based on authority delegated to them by the populace'.$^{5}$ However, the impact of corruption might extend further than personal decisions, as all in all it is 'a departure from what should be ('the norm') in ethics, morality, tradition, law, and civic virtue'. 6

Corruption is any intentional act based on a conscious decision to act in dereliction of duty and breach of ethical and legal norms. Therefore identifying which transactions or behaviour are corrupt is greatly dependent not only on historical, social, and economic settings, but also on the normative and moral context of such behaviour.

In Hungary under communist rule, ideological corruption, taken in a broad sense, caused the disintegration of the belief system and the state itself, as rules were misapplied to the power holders' own advantage. ${ }^{7}$ Society was divided over whether or not its members had access to sufficient power for them actually to be corrupt. Corruption was in fact seen as an essential means of greasing the wheels of the shortage economy that was creating a lack of important social goods. Informal payments represented state consent to petty corruption intended to improve quality of life. ${ }^{8}$ In addition to the evident economic perks, corruption was tolerated to prevent social and political unrest.

${ }^{4}$ Barney G. Glaser / Anselm L. Strauss, The Discovery of Grounded Theory. Strategies for Qualitative Research, Chicago 1967, 45.

5 William A. Darity, ed, International Encyclopedia of the Social Sciences, Detroit/MI 2008, 144 .

6 Alina Mungiu-Pippidi, Corruption. Political and Public Aspects, in: James D. Wright, ed, International Encyclopedia of the Social and Behavioral Sciences, vol. 5, Amsterdam 2015, 12-20, 12.

7 Petra Burai, Transitioning Boundaries Between Law and Social Practice. Corruption in Hungary Before and After 1989, in: Balázs Fekete / Fruzsina Gárdos-Orosz, eds, Central and Eastern European Socio-Political and Legal Transition Revisited, Frankfurt/M et al. 2018, 89-103, 92-93.

8 Csaba Horváth, A korrupció társadalmi gyökerei (a Kádár-rendszer), in: Ferenc Csefkó / Csaba Horváth, eds, Korrupció Magyarországon, Budapest 2001, 71-82, 74-75. 
Systematic and pervasive misinterpretation meant that exceptions to the legal order multiplied and eventually became the rule. ${ }^{9}$ The communist era therefore produced its own social values, norms and customs such as toleration of informal 'gratitude payments' in the health care sector, and the close-knit network of the nepotistic nomenklatura. ${ }^{10}$ Furthermore, traditional practices like gift-giving, bargaining, and reliance on networks or kinship have been widely perceived as inseparable from social reality and corruption. ${ }^{11}$

After the political and economic transition of 1989 ordinary citizens and health workers alike found themselves overwhelmed by unstructured and unprecedented normative pluralism, hence becoming 'increasingly vulnerable in an unregulated public sphere' ${ }^{12}$ One way to relieve the new pressure of everyday moral choices and legal contradictions was to accept corruption as a natural element of everyday life, particularly in the health care system which played so important a part in every citizen's life. Thus informal payments sustained the practice of corruption in Hungary, and still shape perceptions of it.

\section{Informal Payments and the Hungarian Health Care System}

For the majority of Hungarians everyday corruption in the health system revolves around hálapénz which means literally 'gratitude money', or paraszolvencia, from the Graeco-Latin 'parasolventia' meaning 'things that help to solve other things' as well as 'the ability to pay extra' ${ }^{13}$ Defined broadly the term hálapénz denotes any informal payment over and above their formal and regular state-provided pay and expenses made by or on behalf of patients to a doctor or health sector employee for their services. As such, hálapénz includes numerous forms of informal payments such as "'brown envelope" payments to physicians and "contributions" to hospitals as well as the value of medical

${ }^{9}$ Carl J. Friedrich, Corruption Concepts in Historical Perpective, in: Arnold J. Heidenheimer / Michael Johnston, eds, Political Corruption. Concepts and Contexts, New Brunswick/ NJ, London 2002, 15-23, 17.

10 Caroline Humphrey / David Sneath, Shanghaied by the Bureaucracy. Bribery and Post-Soviet Officialdom in Russia and Mongolia, in: Italo Pardo, ed, Between Morality and the Law. Corruption, Anthropology and Comparative Society, Aldershot 2004, 85-99, 87.

11 Alexandru V. Roman / Hugh T. Miller, Building Social Cohesion. Family, Friends and Corruption. Administration and Society 46, no. 7 (2014), 775-795, 786, DOI: 10.1177/0095399712473987.

12 Michele Rivkin-Fish, Bribes, Gifts and Unofficial Paymets. Rethinking Corruption in Post-Soviet Russian Helath Care, in: Dieter Haller / Cris Shore, eds, Corruption. Anthropological Perspectives, London 2005, 47-64, 63.

${ }_{13}$ For the linguistic origins of the terms see A paraszolvencia hungarikum, Nyelv és Tudomány, 12 July 2012, http://www.nyest.hu/hirek/mi-az-a-paraszolvencia. 
supplies purchased by patients and drugs obtained from private pharmacies but intended to be part of government-financed health care services' ${ }^{14}$

If analysed under Claude Lévi-Strauss's anthropological typology of exchange methods hálapénz payments are rather restricted and closed exchanges involving two partners in which money or gifts are given for actual or anticipated services. $^{15}$

\section{Medical Workers $\leftrightarrow$ Patients}

Defined narrowly, as phrased by the Code of Ethics of the Hungarian Medical Chamber, 'gratitude money or gratitude service is any kind of advantage or allowance that is given to the doctor by the patient or his/her relatives $s u b$ sequently, without being requested, if that do not influence the quality of the care by any means. Expressing gratitude can only be voluntary'. ${ }^{16}$ Under the conditions set by its narrow definition hálapénz is only one type of 'under-thetable' transaction between doctors, health care workers and patients, or other interested parties, mostly relatives.

If the conditions of the narrow definition are fulfilled, the payments are widely perceived as exempt from normally applicable legal consequences, although in practice the boundaries between criminal bribery and informal payments are often blurred. Informal 'gratitude payments' create a comprehensive system of ways and transactions through which patients, physicians and other relevant parties engage with the healthcare system.

From the end of World War II until 1989, for most of their lives, the interview subjects were all beneficiaries of the free Hungarian state health care scheme. According to Article 47 (1) of the 1949 Socialist Constitution the state undertook to protect the health of workers by providing extensive social security and by organizing medical care. After its 1989 and 1990 amendments the Constitution prescribed that the Republic of Hungary must contribute to the highest possible standard of physical and mental health by, inter alia, ensuring safety at work as well as healthcare institutions and medical cover. ${ }^{17}$

14 Maureen Lewis, Governance and Corruption in Public Health Care Systems. Center for Global Development Working Paper 78, 2016, 26, http://ssrn.com/abstract=984046.

15 Claude Lévi-Strauss made a significant differentiation between the methods of restricted and generalized exchanges. According to his typology 'alongside and beyond exchange in its restricted sense, i. e., involving only two partners, there may be imagined, and there exists, a cycle which is less immediately discernible. Precisely because it involves a more complex structure. It is that we give the name "generalized exchange"'. Claude Lévi-Strauss, The Elementary Structures of Kinship, Boston 1969, 233.

16 Point II.15. (1) of the Code of Ethics of the Hungarian Medical Chamber as adopted 24 September 2011 and in force from 1 January 2012 (emphasis added, P.B.).

17 Article 70/D (1) and (2) of Act XX of 1949 on the Constitution of the Republic of Hungary as amended by Act XXXI of 1989 and Act XL of 1990. 
Since the political transition of 1989 and the relevant regulatory changes of 1990 the Hungarian healthcare system has functioned as a compulsory national health insurance scheme based on a compulsory levy at a fixed percentage of income. ${ }^{18}$ It provides universal access to treatment mainly in publicly financed hospitals and general medical practices. ${ }^{19}$ Although the political transition has opened the way for a sustainable private sector in health care, developments have tended rather to become intertwined with the public sector than to be separated from it. ${ }^{20}$

Thus the health care system has turned out to be a combination of a publicly funded general insurance scheme and private practices run mostly by physicians alongside their public employment. The funding and investments made by state and local communities have been topped up by 'pocket-to-pocket' or 'under-the-table' payments collected directly from patients. ${ }^{21}$ According to the data of the Central Statistical Office physicians working at hospitals received Ft 4.1 billion (EUR 127,680,000), General Practitioners (GPs) and specialist doctors Ft 2.5 billion (EUR 7,785,495), and dentists Ft 1.1 billion (EUR 3,425,620). Meanwhile, in 2014 nurses and medical assistants were given Ft 508 million (EUR $1,582,000$ ) as hálapénz. The total of Ft 8.3 billion amounted to $0.08 \%$ of the annual income of Hungarians. ${ }^{22}$

Bureaucratic state control and hierarchical organization within healthcare institutions have contributed to the highly ambiguous environment. ${ }^{23}$ Meanwhile, hálapénz has become a ritual understood by all, implying special behavioural norms and tariffs applied by all parties concerned and spread by word of mouth. As such, informal payments regarded as bribes, fees and rewards have grown into a semi-recognized even if simultaneously semi-condemned part of the legal system. In time too, knowledge of sums payable and the expectations of individual physicians regarding treatment has become increasingly available

18 In 2015 the percentage set by law as a main rule was 27\%. See Act CXVII of 1995 on personal income tax, Section 29.

19 Ágota Szende/ Anthony Johr Culyer, The Inequity of Informal Payments for Health Care. The Case of Hungary, Health Policy 75, no. 3 (2006), 262-271, 264, DOI: 10.1016/j.healthpol.2005.04.001.

20 Peter Gaal et al., Informal Payments for Health Care. Definitions, Distinctions, and Dilemmas, Journal of Health Politics, Policy and Law 31, no. 2 (2006), 251-293, 274, DOI: 10.1215/03616878-31-2-251.

${ }^{21}$ Gaal et al., eds, Informal Payments for Health Care, 275.

${ }^{22}$ Központi Statisztikai Hivatal, Borravaló és hálapénz, 1 April 2015, http://www.ksh.hu/ docs/hun/xftp/stattukor/halapenz.pdf.

23 Géza Bognár / Iván Róbert Gál / János Kornai, Hálapénz a magyar egészségügyben, TÁRKI Társadalompolitikai Tanulmányok 17, Budapest 1999, 41, http://mek.oszk. hu/13700/13749/13749.pdf; János Kornai, Hidden in an Envelope. Gratitude Payments to Medical Doctors in Hungary, in: Lord Dahrendorf et al., eds, The Paradoxes of Unintended Consequences, Budapest 2000, 195-212. 
via the internet. Indeed, websites such as fizettem.hu have been established to collect experiences of paying different hálapénz tariffs. ${ }^{24}$

In 2015 physicians launched new initiatives in protest against gratitude payments and there is now a social media group of medical professionals who do not accept hálapénz from patients. ${ }^{25}$

\section{Past and Current Paradoxes Surrounding the Legal Regulation of Gratitude Payments}

Before World War II, giving gifts to doctors was an acceptable way to pay set fees in kind. Then, due to the communist nationalization process in the 1950s physicians had to give up their private practices to become public employees. However, despite a general ban on all forms of informal payments, low state salaries paved the way for an ever-growing system of informal transactions. ${ }^{26}$ The legislation most relevant to the information gained from the life-story interviews was the Criminal Code of 1978, which was in force until superseded by the Criminal Code of 2012. ${ }^{27}$

In theory, hálapénz transactions involve all parties in violation of their obligation enshrined in Act CLIV of 1997 on health, according to which each and every individual shall respect the rights of others to the promotion and protection of their health, and of their obligation to prevent disease and restore good health. ${ }^{28}$ However, in practice, policy makers, regulators, and courts have all recognized a difference between informal payments and true corruption and have legitimized hálapénz. Hungarian officialdom took the view that gratitude payments were in fact not prohibited and in 2004 the Minister of Health even requested the Chief Public Prosecutor to review how the law and courts related to hálapénz exchanges. ${ }^{29}$

24 Átlátszó Oknyomozó Újságíró Központ (Atlatszo Investigative Journalist Center), Collection of personal accounts of gratitude payments, http://www.fizettem.hu/bejelentesek/ fizettek/mindenmegye/mindenvaros/eg\%C3\%A9szs\%C3\%A9g\%C3\%BCgyi_\%C3\%A9s_szoci\%C3\%A1lis_int\%C3\%A9zm\%C3\%A9nyek?page=6.

${ }^{25}$ As of 31 December 2015 the group had 1,901 members, https://www.facebook.com/ groups/383842128454569/?fref=ts.

26 György Ádám, Az orvosi hálapénz Magyarországon, Budapest 1986, 58, 67.

27 As to the bribery committed by medical workers the Criminal Code of 1978 prescribed that 'any employee or member of a budgetary agency, economic operator or association who requests an unlawful advantage in connection with his actions in an official capacity, accepts such advantage or a promise in exchange for violating his responsibilities or agrees with the party requesting or accepting the advantage is guilty of a felony punishable by imprisonment for up to three years'. Act IV of 1978 on the Criminal Code, Section 251 (1).

28 Act CLIV of 1997 on Health, Section 5 (2).

29 Position of the Chief Public Prosecutor about the gratitude payment (No. NF.388/2004/5). 
After the new Criminal Code came into force in 2013 the scope of the law widened once again. ${ }^{30}$ The 2013 regulation imposes sanctions on any individual who accepts an unlawful advantage before or after medical treatment even if professional duties are not violated. It is important to note that before 2013 such stringent regulation had applied only to those doctors who-acting in their official capacity - were entitled to take measures independently and who were empowered to make decisions about, for example, the transfer of patients to specialist medical facilities, or about eligibility for disability pensions. ${ }^{31}$

For patients, their relatives or other parties involved who actively took the initiative and gave or offered payments to medical workers the Criminal Code of 1978 prescribed a punishment of up to two years of imprisonment for committing what was officially a misdemeanour. ${ }^{32}$ If their intention had been to induce a doctor to violate his or her official duty, exceed his or her competence or otherwise abuse his or her official position that became a crime with the sanction of imprisonment for up to three years. ${ }^{33}$ Until 2002 such perpetrators, on the other hand, were not punishable, if they had given or promised the favour upon the initiative of the person acting in an official capacity out of fear of suffering unlawful disadvantage or of not acting as expected..$^{34}$

Pursuant to the law in force there is no such exemption referring to fear of retaliation, but the Criminal Code of 2012 allows for the unlimited reduction of an imposed penalty if the perpetrator, in person, admits the action to the authorities and reveals the circumstances of the crime. ${ }^{35}$ The current Criminal Code also sets longer prison terms for active corruption.

At the same time, Act CXVII of 1995 on personal income tax explicitly states that hálapénz is taxable income, but neither defines how the term shall be understood under the law, nor deals with the question of criminal liability if -in

30 According to the Criminal Code of 2012, 'any person who requests or receives an unlawful advantage in connection with his activities performed for or on behalf of an economic operator, for himself or for a third party, or accepts a promise of such an advantage, or is in league with the person requesting or accepting the advantage for a third party on his behest, is guilty of a felony punishable by imprisonment not exceeding three years.' Act C of 2012 on the Criminal Code, Section 291 (1).

31 Act C of 2012 on the Criminal Code, Section 292 (1); Ádám, Az orvosi hálapénz Magyarországon, 188.

32 Act IV of 1978 on the Criminal Code, Section 253 (1).

33 Act IV of 1978 on the Criminal Code, Section 253 (2).

34 Act IV of 1978 on the Criminal Code, Section 253 (3) until Section 40 of the Act CXXI of 2001 amended the provision after the ratification of the OECD Convention on Combating Bribery of Foreign Public Officials in International Business Transactions and Council of Europe's Criminal Law Convention on Corruption and in accordance with the legal harmonization process with the European Union. See the Explanatory Memorandum of the Act Proposal no. T/5060 (later adopted as Act CXXI of 2001) on the amendment of the Act IV of 1978 on the Criminal Code, http://www.parlament.hu/irom36/5060/5060.htm.

35 Act C of 2012 on the Criminal Code, Section 290 (5). 
a highly unlikely scenario-a medical employee happened to declare any income from it. ${ }^{36}$ Nevertheless, all medical workers who do not declare any income from hálapénz may be found guilty of tax fraud (or according to the Criminal Code of 2012, budget fraud). ${ }^{37}$

Under both past and current regulations medical workers and patients face strict criminal sanction for involvement in gratitude payments. To maintain the system of 'banned in principle but permitted in practice' policy makers have found another legal solution to uphold 'the discrepancy between the "de jure" and "de facto" situation'. ${ }^{38}$ The Labour Code (also adopted in 2012) declares that 'employees may not accept and may not claim any remuneration from third parties in connection with their activities performed within the employment relationship without the employer's prior consent. ${ }^{\prime 39}$

In relation to gratitude payments, that regulation might be taken to mean that if an employer permits gratitude payments for example within a hospital's organizational and operational rules, then medical employees would be exempt from criminal consequences as any advantage gained would not be unlawful. Nevertheless, such applicability of the exemption is hotly debated among legal scholars and practitioners. ${ }^{40}$ According to a decision on the principle by the Hungarian Supreme Court (Curia) the provision set in the Labour Code might be relevant only to disputes under employment law and to disciplinary procedures. ${ }^{41}$

\section{Gaining an Advantage. Personal Motivations behind the Hálapénz Exchanges}

The hálapénz system has evolved over the lifetimes of the respondents, so it was hardly a surprise that each of them had been involved in such transactions.

36 Point 7.2. of Appendix 1 to the Act CXVII of 1995 on personal income tax.

37 According to Section 396 (1) of Act C of 2012 on the Criminal Code 'any person who a) induces a person to hold or continue to hold a false belief, or suppresses known facts in connection with any budget payment obligation or with any funds paid or payable from the budget, or makes a false statement to this extent; b) unlawfully claims any advantage made available in connection with budget payment obligations; or c) uses funds paid or payable from the budget for purposes other than those authorized; and thereby causes financial loss to one or more budgets, is guilty of misdemeanor punishable by imprisonment not exceeding two years'.

38 Gaal et al., eds, Informal Payments for Health Care, 267.

39 Act I of 2012 on the Labor Code, Section 52 (2).

40 See Miklós Hollán's view on the applicability of the exemption. Miklós Hollán, A hálapénz büntetőjogi megítélése - egy törvénytervezet margójára, Jtiblog, 4 May 2015, http://jog.tk.mta. hu/blog/2015/05/a-halapenz-buntetojogi-megitelese.

41 Tájékoztató a Bhar.III.6/2015. számú büntetőügyben hozott, az orvosi hálapénzhez kapcsolódó elvi jelentőségü döntésről, lb.hu, 27 August 2015, http://www.lb.hu/hu/sajto/tajekoztato-bhariii62015-szamu-buntetougyben-hozott-az-orvosi-halapenzhez-kapcsolodo-elvi. 
Due to their age the respondents also fell into the group in society with higher prevalence of gratitude payment as all of them had at various stages of their lives faced more or less complicated medical conditions requiring treatment. Many of the interviewees had made such payments on more than one occasion, although the 'background and motivations of their involvement' differed significantly. A hope for better care was one of the main criteria used to decide whether to make gratitude payments even if one respondent, 'Mrs D', did not in fact generally approve of the hálapénz system:

PB: Do you support giving money to the doctor or the nurse, or anyone in the healthcare sector? Is that alright as far as you are concerned?

Mrs D: Well; it's not good but one does everything to make life better.

PB: And why did you think that if you gave the money it would be better?

Mrs D: I thought, 'we'll get better treatment afterwards'. ${ }^{42}$

The decision to pay was partly the result of fear of otherwise failing to receive good quality treatment. The implied rules of the system also indicate significant peer pressure to participate in such exchanges. 'Mrs B' said that giving money to her GP (háziorvos) was effectively compulsory even if there was no explicit request for such payment, because it had always been the everyday routine. Moreover, she was afraid of being disparaged or even ignored by others, including doctors, for not being grateful enough: ${ }^{43}$

PB: And why does one give [hálapénz] anyway? Only because it's the normal thing?

Mrs B: Rather to stop others saying I didn't pay it. That's part of it, as well.

PB: Are you afraid that you wouldn't get adequate treatment?

Mrs B: Yes, that they wouldn't take the proper care, or something like that.

However, respondents were rather eager to express their personal appreciation and gratitude despite the legal regulations and the criminal implications of them, or other people's opinion. Appreciation encompasses not only professional medical care, but a humane and caring attitude as well as kindness shown by health care workers.

Mrs H: I just wanted to express my gratitude. Really, only to say 'Thank you' to the professor. Both my first and also my second operation had lasted five hours, so I thought that apart from him saving my life, I would very much like to give a gift as well. I would also have very much liked to give something to the nurses who were at my hospital bedside. The doctor helped me with his professional knowledge, while that nurse had contributed with her everyday activities, therefore I wanted to show my appreciation of them, and I did that in fact, in everything. ${ }^{44}$

42 Petra Burai, Personal interview with Mrs D (born 1929), 16 September 2014.

43 Petra Burai, Personal interview with Mrs B (born 1929), 19 September 2014.

44 Petra Burai, Personal interview with Mrs H (born 1939), 17 August 2015. 
Mrs E: When my husband was ill and in hospital here at Eger, we gave some money when the time came for his treatment. Not too much; but because they'd deserved it. Because you see ... well, when someone's nice and wants to help; when they speak to you kindly. ${ }^{45}$

While personal care and attentiveness has been a quality to be highly rewarded, the same might equally have been the main ground for disapproval. Looking at a wider segment of society, according to a 2013 social survey into the relationship between doctors and patients, $50 \%$ of legal cases against doctors were brought because the patients concerned had not been satisfied with their treatment or with communication from doctors. ${ }^{46}$ 'Mrs E' has emphasized the pivotal role of mutual appreciation. She explained her ideal and the characteristics of a doctor she most appreciated by describing a particular GP she knew quite well. Her description outlined an 'assessment method' in which personal values and qualities had seemingly gone before professional attributes:

Mrs E: He used to be a doctor in Heves. Everybody liked him. He knew the people from Tarna as well, as he was born there. He never accepted money from anyone whom he knew was poor. He recognized everybody from Tarna on the road, and greeted everyone, because he was that kind. Everybody respected and appreciated him. We heard about people who were educated and looked down on everyone, boasting about who they were; but everybody's different. He used to be really nice, because during the [1956] revolution when there was no public transport and the trains stopped, we had walked to Heves, because we had to see a doctor, and there wasn't one in Tarna. If he saw that there was anyone from Tarna, he let them in before the others, even if the majority was from Heves. [...] He was wise and everybody liked that $[. .$.$] He was fair.$

In Mrs E's assessment 'general expectations' were governed by prevailing social values and standards intertwined with her own 'particular expectations' of the physician's behaviour and the rewards she associated with him. ${ }^{47}$ Besides being 'kind' and 'fair', small personal favours making the patient more comfortable, and feeling secure, mattered greatly too when assessing the standard of medical staff:

Mrs G: I've had this big-ish operation recently, but I've never been a frequent hospital visitor. I gave money now as well, when I wanted to leave and he was getting the stitches out. Then I gave money, because he deserved it.

PB: But did he ask for it?

45 Petra Burai, Personal interview with Mrs E (born 1927), 15 September 2014.

46 Gyógyításra vár az orvos-beteg jog kérdése Magyarországon, szinapszis.hu, 27 November 2013, http://www.szinapszis.hu/hu/hirek/gyagyitasra-var-az-orvos-beteg-jog-kerdese-magyarorszagon.

47 Following Peter M. Blau's typology of expectations of social rewards. Peter M. Blau, Exchange and Power in Social Life, New Brunswick/NJ et al. 1964, 143-144. 
Mrs G: No, it was me who thought he deserved it, because he even came in to see me on Sunday; he treated me before anyone else. He was very nice. ${ }^{48}$

The respondents' eagerness to give hálapénz in exchange for kindness and compassion might easily be perceived as empirical evidence of solidarity in a balanced exchange. According to the so-called 'donation hypothesis' the gratitude payment is merely a benign sign of the patient's willingly given appreciation for being healed. ${ }^{49}$ Taken as a wholly sincere gesture of reciprocity hálapénz might be considered to be operating as an incentive to enhance the responsiveness of healthcare workers and encourage them to show more commitment to their profession. ${ }^{50}$

However, such an approach simplifies the complex set of motivations behind the carefully considered decisions of patients. For the respondents, money given served too as feedback and evaluation of the medical service they had received.

In general, from the patients' point of view coming under medical treatment is a sensitive as much as a passive situation, burdened with a rather 'hierarchical' doctor-patient relationship in which patients have only limited competence to influence the outcome of the procedure. Therefore for our respondents, hálapénz gave them an opportunity - or at least the illusion of it - to feel a sense of ownership and to be active decision-makers in their own healing process. They felt that deciding how much hálapénz to give, and how and why they should give it restored to patients a feeling that they mattered.

The urge and need to express gratitude and appreciation had even led to situations where the respondents had tried to force medical staff to accept money:

Mr L: The professor shook me off in a minute, he didn't want to accept it, instead I should've been glad that [the operation] was successful. I replied that I could be very tricky, I wasn't going to put up with that just like that! [He told me] not to even think about that, and that I shouldn't send anything through the post, because he wouldn't accept it.

Mrs F: [The chief doctor] operated on my father eleven times, but he didn't accept the money. My mother could only get through to him when the chief doctor had wasn't at home; then we killed the duck and the pig when it was the season for doing that. Then my mother put one or two into her basket, took them to town and gave them to the [doctor's] wife. But his wife always asked whether they had agreed on that? We just told a fib and said, 'Yes!'! ${ }^{51}$

Overcoming doctors' resistance under such circumstances has also become a question of honour. Resourcefulness and wit has often been considered as an asset in the quest:

\footnotetext{
48 Petra Burai, Personal interview with Mrs G (born 1938), 11 August 2015.

49 Gaal et al., eds, Informal Payments for Health Care, 255.

50 Gaal et al., eds, Informal Payments for Health Care, 255-256.

51 Petra Burai, Personal interview with Mrs F (born 1936), 18 September 2014.
} 
PB: Why didn't you give money, if you don't mind my asking?

Mrs F: Because, as I'd observed, the chief doctor didn't ask for it. Only if one used force and put [hálapénz] into his pocket, only then did he not gave it back. I thought if he was unresponsive, well then, I had to act accordingly. When I left and had to go back after a month I took him [hálapénz]. Then that was what I did; I knew how to do it.

PB: You knew that you would have to put it into his pocket, and then he wouldn't give it back?

Mrs F: Yes; I didn't want to leave [without paying].

It should be noted that in most research studies such coercion has dominantly been linked to medical staff. ${ }^{52}$ Therefore it is important to see that the rather utilitarian attitude and evident pressure exerted by patients striving for power itself results in skewed reciprocity in hálapénz exchanges.

\section{The Tariff of the Advantage. Deciding What and How Much to Give}

In general, hálapénz can take various forms. Other than actual money, informal payments in kind range from 'tangible gifts, such as sweets and alcoholic drinks, or more expensive items, such as works of art or jewellery, to services provided by the patients or their relatives, and political favors' ${ }^{53}$ Gifts have mostly been seen as the traditional form of allowance given by those who could more easily offer home-bred poultry than money. Money, on the other hand, has the obvious advantage of being less complicated to hand over, while the recipient can spend it however desired. Physicians have therefore traditionally preferred 'brown envelopes' containing notes over gifts in kind:

Dr K: Having an envelope pressed into your pocket is the easiest. At the hospital that looked much better than some peasant woman coming in with four chickens or a hen in her bag. I had colleagues who said they answered the granny who asked about how she could be grateful by saying, 'I told her that the Phoenicians invented it 5,000 years ago, so there is no need to even think about it any longer' ${ }^{\prime}{ }^{4}$

According to the respondents there has always been a clear hierarchy between doctors and other medical staff which was reflected in the amounts each received. While doctors were almost always given money, the performances of nurses were acknowledged with gifts - of lesser worth:

Mrs G: The nurses were very kind as well. I took coffee and chocolate for them, because [my partner] had been there for three weeks and they cleaned and shaved him.

52 Gaal et al., eds, Informal Payments for Health Care, 256.

53 Gaal et al., eds, Informal Payments for Health Care, 261.

54 Petra Burai, Personal interview with Dr K (born 1945), 23 August 2015. 
There has been a noticeable shift over the years from gifts to money. Initially, doctors who felt uncomfortable accepting money took gifts instead, but in the course of time attitudes on both sides have changed. Things have changed for practical reasons too as peasant life ceased to exist with the growing impact of urbanization.

The respondents identified two main points about their own expectations and about how they decided how much money to give. The first is what they learn from fellow patients as 'reference standards' especially in terms of what benefits could have been obtained in similar situations: ${ }^{55}$

PB: When you gave money how did you decide about the amount?

Mrs G: Honestly? I asked how much an operation like that would cost. One asks around to find out how much others gave or think they should give.

PB: Who do you ask around about that?

Mrs G.: The patients; among each other.

The second thing determining how much to give is the level of satisfaction with the qualities and services provided by the medical staff. Clearly then, patients' own ideas and expectations about the ideal treatment and the personal merits of the medical staff introduced above set the overall standard about whether to give money or not:

PB: How did you decide how much money to put into the envelope?

Mrs H: Only what we'd talked about among ourselves; with the other patients.

PB: Was it a kind of unwritten tradition going round?

Mrs H: And then I decided to deduct from or add to it depending on if the person deserved it for his kindness. For that, I was thinking above all whether he was compassionate enough. I'd survived the operation because of his professionalism, but his compassion would be even more important.

The medical staff, including the doctors, were also fully aware of these unwritten hálapénz tariffs. Nevertheless, they recognized too that patients tend to want to outdo each other when they talk about how much money their envelopes contain:

Dr K: We call that the 'patient psychosis'; you have to know about it. If there's a hospital room with eight beds, and one of the patients gives the doctor $\mathrm{Ft} 3,000$, he'll surely tell his fellow patients that he gave him Ft 5,000!56

What Dr K called 'patient psychosis' has been complemented by a survey done by TARKI Social Research Centre on hálapénz in 1999. Of 740 respondents taking part in quantitative research $36 \%$ claimed that in hospitals others had given more hálapénz than they had; $6 \%$ thought that others had paid less, while $23 \%$

55 Blau, Exchange and Power in Social Life, 143.

${ }^{56}$ HUF 3000 equals to ca. EUR 10 and Ft 5000 is ca. EUR 16. 
assumed that everyone had given the same, compared to 35\% who said that they did not know how much others had given. ${ }^{57}$

There is only one conclusion to be drawn with certainty from those replies. The boundary between 'knowing' and 'not knowing' is scarcely evident for the patients, at least according to what the interviewees said. Their replies to interview questions certainly cast a different light on the quantitative statistical results. The extent of such 'not knowing' presumes only that most patients do not really know exactly how much hálapénz others give, but they do 'know' the 'basic tariffs' as starting points for their own deliberations about how much they themselves should give.

Although the respondents did not indicate it, as mentioned before the hálapénz tariffs might have been discussed not only individually among the patients, but might have been widely disseminated in print and broadcast media. For example, the daily tabloid Blikk has published a comprehensive list of treatments and their informal prices under the heading 'We present you the tariffs'. The paper had collected its information from on-going discussions on internet forums. ${ }^{58}$

According to the newspaper article, for a brain operation for example, one should pay Ft 150,000 (EUR 480), or Ft50,000 (EUR 160) for breast cancer surgery. Cardiac surgery costs Ft 170,000 (EUR 545) while a gratitude payment for giving birth was reckoned at $\mathrm{Ft} 200,000$ (EUR 640). In comparison, data from the Hungarian Central Statistical Office reveals that the average monthly net salary was Ft 159,308 (EUR 512) in 2015 and in 2014 the average monthly pension was Ft 116,000 (EUR 374).${ }^{59}$ Consequently, more serious surgery or paying hálapénz for giving birth might place an excessive burden on an individual or household while providing significant additional income for medical workers.

\section{The End of a Medical Affair}

The regulations of the 1978 Criminal Code distinguished between benefits gained before and after treatment. That differentiation was important since the law imposed sanctions if the hálapénz was given or received before treatment was provided. Although the regulation currently in force makes no such differentiation, established practice and the examples given by our respondents prove that timing, particularly the beginning and the end of the transaction is a highly relative question as far as the determination of hálapénz is concerned.

\footnotetext{
57 Bognár / Gál / Kornai, Hálapénz a magyar egészségügyben, 36-37.

58 Félelemből adjuk a hálapénzt, blikk.hu, 22 September 2014, http://www.blikk.hu/blikk_aktualis/felelembol-adjuk-a-halapenzt-2288937.

${ }^{59}$ Hungarian Central Statistical Office, Average monthly net salary of the employed, http:// www.ksh.hu/docs/hun/xstadat/xstadat_eves/i_qli012b.html; Központi Statisztikai Hivatal, Nyugdíjak és egyéb ellátások, October 2014, https://www.ksh.hu/docs/hun/xftp/idoszaki/ regiok/orsz/nyugdij/nyugdij14.pdf.
} 
Mrs C has always maintained a very good personal relationship with her GP. Being a tradeswoman, for some decades she gave her doctor and his wife gifts. Therefore she was convinced that her past offerings had contributed to her doctor's current kindliness towards her even though she now considers herself too poor to offer any further hálapénz:

Mrs C: They came to the market, he and his wife, because those doctors very much liked to visit the market. We sold our goods there at the mill, and he came with his wife. I had a really nice covered stall, eight metres long, and sold menswear, suits, jackets, silk shirts, linen shirts, and linen trousers. I immediately packed anything Márti, his wife, saw and liked. I must also add that he is still my doctor!

PB: So that relationship has evolved into a friendship?

Mrs C: It's never stopped being a friendship; I'm terribly proud of that. ${ }^{60}$

Evidently, long-term relationships as well as delayed or recurring transactions between doctors and patients might always become very complex and extend far beyond the scope of the criminal definition of bribery. In addition to the fluctuating boundaries between 'before treatment' and 'after treatment' the thin lines dividing advantages gained from gifts, personal favours, friendly relationships and business have sometimes become completely blurred as in case of Dr K. He apparently distinguished between informal payments, particularly money, and gifts in kind from 'friends of friends'. He had accepted the latter as legitimate rewards for his services ('favour for favour') for a number of decades:

Dr K: We've had such a good relationship that I've never accepted any [hálapénz] in an envelope from them. Even when they came with a thick envelope, I refused it. On the other hand, they've always given me what they grew or bred. When I went hunting with them on their land, my car was always full when I came back. They ambushed me! They'd slaughtered a pig for Christmas and gave me a ham at Easter! I can't say I didn't accept it, because I did. But those were all friendly gestures.

\section{Violating Responsibilities. The Limits of Gratitude and Tolerance}

Each respondent had an overall positive attitude to giving hálapénz to medical staff who, according to them, acted appropriately enough to deserve such payments. While most of the respondents had also made up their minds about when not to give, it was clear too that the limits of gratitude might be very different, which might cause rifts among relatives and friends. Over thirty years, 'Mrs $\mathrm{H}^{\prime}$ had three brain operations and always gave the doctors who had carried out the operations sums of money. However, her husband had been against the idea of her paying. He had argued that the doctors' work should not have

60 Petra Burai, Personal interview with Mrs C (born 1943), 18 September 2014. 
been treated any differently from Mrs H's teaching job, which Mr H considered equally demanding. Mr H's view reflected those of many people who dismissed the extra income of the medical sector as 'unjust', when compared to the position of other professions where giving hálapénz has never been the custom:

PB: May I ask if you've given money?

Mrs H: Always; it was my decision. My husband was angry about it but he accepted that it was my decision. He used to say that when I corrected the children's assignments, you got nothing in exchange, it was part of the job. [...] But no; I wanted to express my gratitude.

In practice, giving hálapénz out of gratitude or even fear indicates a certain, albeit varying tolerance of the phenomenon. Nevertheless, if the unwritten and highly personal boundaries of kindness or professionalism are crossed, tolerance diminishes.

A typical example of that is the apparent difference between private and public care, and the level of service implied. There are patients like 'Mrs B', who would be ready to pay hálapénz to obtain the same quality of treatment and personal attention from her GPs - whom she sees regularly - as from doctors in private practice. If medical staff refuse payment, the dissatisfaction of patients often leads to condemnation of the doctors concerned. Mrs B also perceived her being rejected by a physician as a dysfunction of the hálapénz system which she understood well otherwise, and used to her own advantage:

Mrs B: The majority of problems are related to the GPs. They don't care [for patients] like the private ones do, who examine me from head to toe. If I'm registered with a GP, why doesn't he examine me, when I'm ill? He doesn't ask for money, because he's not allowed to, but he is stolid. But if I go and see a private doctor, he does examine me from head to toe. He questions me thoroughly.

Doctors too are able to take advantage of that ambiguous environment and the blurred lines between 'public' and 'private'. The interview subjects mentioned numerous examples of physicians checking on their privately paying patients in hospitals, thereby using publicly funded state facilities to earn private income. Such an attitude was seen as unprofessional and barely to be tolerated, as Mrs B explained:

Mrs B: I have a friend who sees her doctor at the hospital. The doctor makes her pay for everything, including the electricity.

PB: The doctor asks money for using electricity?

Mrs B: Yes.

PB: Was that a private practice?

Mrs B: No, because he was at the hospital. That's for the hospital, isn't it? I asked her why she paid. She said because he was kind, but that's not kindness at all. 


\section{Performing Duties. The Doctors' Reactions}

Dr K's highly complex moral code proves that there have been numerous angles from which medical professionals have approached the question of hálapénz. Accordingly, the interview subjects too had had diverse experiences of the attitudes and reactions of doctors and nurses. First of all, accepting hálapénz in practice is hardly an easy or self-evident step. A number of the physicians whom the respondents had met beforehand apparently felt embarrassed and tried to refuse it, or accepted money only reluctantly:

PB: And how did the doctors react when you gave them the money?

Mrs G: They were embarrassed. The doctor in Eger blushed bright red, but the one in Miskolc was embarrassed as well; he said, "No, no ...!".

Respondents had met doctors who had rejected hálapénz in consideration of the financial situation of the patients. Mrs D's doctor, for example, turned it down claiming that Mrs D seemed in much greater need of the money. That is often called the 'Robin Hood' principle and assumes that such physicians act on their own moral commitment to 'charge rich patients informally and provide services free of charge to poor patients'. ${ }^{61}$ However, quantitative findings have proved that such a generalization is not really valid, as sums of informal payments in Hungary are not related to patients' ability to pay. ${ }^{62}$

The individual experience of respondents too undermines the supposed 'Robin Hood' principle. According to Mrs $\mathrm{H}$ her physicians were quite open and straightforward when they took her money. They were also aware of the possible legal consequences depending on the timing of the exchange:

PB: Have you ever heard about a doctor who refused to treat someone or provided inferior treatment because the patient didn't want to pay?

Mrs H: No. Though I have heard about the husband of a fellow patient of mine who wanted to give the doctor an envelope the morning she went into hospital. The doctor wouldn't accept it then, but he said he would after the patient got better. The husband was in a hurry, but the doctor wouldn't accept anything before the check-ups.

However, it was not obvious to Mrs $\mathrm{H}$ whether the physician concerned was answering to his conscience or rather was taking the legal implications into consideration. According to Dr K his personal moral code did not allow him to receive hálapénz before treatment although he met many desperate relatives who would offer significant sums of money before life-saving operations should be

61 Tetiana Stepurko et al., Informal Payments for Health Care Services. The Case of Lithuania, Poland and Ukraine, Journal of Eurasian Studies 6, no. 1 (2015), 46-58, 49, DOI: 10.1016/j. euras.2014.11.002.

62 Szende / Culyer, The Inequity of Informal Payments for Health Care, 270. 
carried out. Dr K stressed several times in the course of the interview that he has always put the patients' health and interests first.

Individual examples and leading role models have had a more important impact than regulations on medical professionals' attitudes. Dr K emphasized that although his colleagues almost never discussed hálapénz among themselves, everybody knew that the chief doctor had always refused gratitude payments. Nevertheless, in time the chief doctor had relaxed his vigilance; and particularly after the political transition in 1989 the moral code of doctors in general has changed. Requests for hálapénz have become more frequent and direct. Mrs H underwent operations in 1976, 1993 and 2006 and over those three decades she observed a very visible shift in doctors' attitude:

Mrs H: They've always been very kind and nice to me. However, the last time when I was there [in hospital] I was surprised to hear how openly they talked about [hálapénz]. It was only two of us in the room, there had been a general check-up and several doctors came in to see us. They began to talk among themselves and then one of them said something so loud that we heard it in our beds as well. 'That spinal surgery will cost Ft 60,000 but the other will be more expensive, Ft 80,000.' I was just trying to keep up. They were talking so openly about the tariffs they were asking for. At least they could've spoken more quietly, or gone to a different room. [...]'

\section{The Paradox of Retaliation and the Abuse of Power}

Because of the authority and power vested in selected physicians to make binding administrative decisions, refusal to give hálapénz might have had serious consequences not only in the loss of necessary care but also in missing state benefits and allowances related to the health status assigned on diagnosis to individuals. Mrs D's husband had worked with poisonous chemicals that had affected his health. When his eyes, mouth and nose all began to bleed at the same time, he had to be taken to hospital in Eger. Because of his medical condition his salary was withheld. Afterwards, Mrs D began to campaign to receive the state health allowance which the law said her husband was entitled to:

Mrs D: Then I wanted to give money to Doctor Z. My daughter Mari said 'Mother, we're not going to give; you're poor as well. We won't give money'. Then Doctor $\mathrm{Z}$ withdrew the [diagnosis of] occupational disease.

PB: So he didn't ask for the money, but when he didn't receive it, he withdrew the [entitlement to] allowance?

Mrs D: Yes, because I used to give him money regularly beforehand. But Marika said, 'Mother, we won't give'.

PB: Have you lodged an appeal against it?

Mrs D: No. [...]

PB: So you haven't gone to the police, or other authorities either?

Mrs D: It's got nothing to do with them. 
Mrs D's case holds a number of lessons. On the one hand, the arbitrary and presumably corrupt decision of the physician concerned could hardly have been used in any legal claim because of the lack of hard evidence, despite the substantive harm and financial damage it had caused to Mrs D and her family. On the other hand, neither Mrs D nor her family took any actual steps against the doctor. They did not consult the legal regulations in force, nor did they consult the competent authorities to enquire about their options. Instead, Mrs D was convinced that although her family had suffered clear detrimental consequences, the authorities had no role in the affair.

Mrs D's overall resistance to the authorities reflects ordinary people's lack of willingness to report corruption and the infringement of medical rights. According to a medical survey $90 \%$ of patients who were not satisfied with their treatment decided not to make their claims or problems known. ${ }^{63}$

\section{Concluding Thoughts. The Myth of Reciprocal Satisfaction and the Impossibility of Adjudication}

Throughout the decades there have been numerous academic signals, professional warnings and judicial acknowledgments indicating that the hálapénz phenomenon has become an 'epidemic' and 'systematic' social practice in Hungary. The thoroughly researched and well-grounded reasons given included low salaries of medical professionals, lack of funding for high quality services in healthcare institutions, an obsolete insurance system and the legacy of the socialist shortage economy with its blurred boundaries between public and private services. ${ }^{64}$

The obvious discrepancy between hálapénz tariffs and the incomes of medical workers referred to above clearly indicates that the economic dimensions of the hálapénz phenomenon cannot be ignored as far as sectoral policies and structural reforms are concerned. At the same time, applying the fundamental concepts of 'exchange' and 'reciprocity' established in (legal) anthropology to the respondents' experiences and the relevant case law complements the problems above by highlighting an equally significant, but mostly disregarded lesson which can be conceptualized as 'the myth of reciprocal satisfaction'.

In the respondents' case, deliberations and decisions were made in very closed, often secretive relationships and were based on unclear information

63 The most common reasons for patient dissatisfaction were 'disappointing communication between doctors and patients', 'lacking adequate diagnosis and care', 'lacking information', 'long waiting times', and 'disregarding the patient's request for a particular treatment'. See Gyógyításra vár az orvos-beteg jog kérdése Magyarországon.

${ }^{64}$ Mária Petschnig, Az orvosi hálapénzről - nem etikai alapon, Valóság 11 (November 1983), 47-55; Péter Mihályi, A hálapénzről - talán utoljára, Egészségügyi Gazdasági Szemle 42 (2004), 5-21, 8-11. 
about tariffs. Such decisions were influenced by often conflicting expectations and moral codes. Some of the restricted exchanges evidently encompassed putatively altruistic 'general reciprocity' as well as reciprocation of equivalent value; that is, 'balanced reciprocity'. ${ }^{65}$

Nevertheless, under the facade of 'gratitude' personal strategies included psychological pressure, manipulation or even outright coercion by both patients and medical staff. Exchanges did not therefore always result in clear reciprocal satisfaction. In fact, only a minority of the parties involved were able either to acquire or offer definite satisfaction as there was no obvious outcome for any treatment. In hálapénz transactions the form and value of the exchangeable goods is highly subjective, being transformed by time and social changes.

Policy makers and legislators have reacted to hálapénz by either passively tolerating the practice, or enacting narrowly applicable yet keenly debated legal exemptions on the assumption that such informal payments are balanced and honest exchanges, between mutually satisfied partners in equal positions. The term 'gratitude' (hála) has had the connotation of being healed in a harmonious and, most importantly, balanced co-existence and interdependence. The myth of reciprocal satisfaction has legitimized the payment of hálapénz as a self-evident attribute of organic solidarity, social cohesion, and economic cooperation in the healthcare system. ${ }^{66}$

By contrast, the testimonies of the respondents show that the threshold between morally acceptable and legally punishable has been variable from case to case. Although many respondents claimed that their exchanges were mutual and voluntary, reading between the lines we see a more complex picture. The empirical evidence of the interviews also highlights particularly imbalanced transactions between medical workers and patients.

Importantly, the respondents did not see their informal payments as an infringement of their right to health care. Instead, they regard hálapénz as a means to bolster their position in the doctor-patient relationship, gain control of their

${ }^{65}$ Marsall D. Sahlins, On the Sociology of Primitive Exchange, in: Michael Banton, ed, The Relevance of Models for Social Anthropology, London 1965, 139-236, 148.

${ }^{66}$ I define 'organic solidarity' following Emile Durkheim's argumentation regarding the interdependence that is the consequence of the specialization of work and the complementarities between people in modern industrial societies: 'Around their purely professional functions will be grouped others which at present are exercised by the communes and private associations. Among these are functions of mutual assistance which, in order to be entirely fulfilled, assume between helpers and helped feelings of solidarity as well as a certain homogeneity of intellect and morals, such as that readily engendered by the exercise of the same profession.' Emile Durkheim, The Division of Labor in Society, 1893. As published in David B. Grusky / Szonja Szelènyi, eds, Inequality. Classic Readings in Race, Class, and Gender, Cambridge/MA 2006, 55-63, 61. 
situation and influence decisions related to them. ${ }^{67}$ The respondents sometimes even strengthened the restrictive nature of the exchange by voluntarily excluding the authorities from their affairs. In that sense, superficially at least the Curia's solution of accepting hálapénz under certain circumstances as a social custom has reinforced and fulfilled existing demand for self-initiative and balanced reciprocity.

There are obvious risks in building a legal principle on the myth of satisfactory reciprocity. The Curia makes decisions on principle, to promote legal standardization and avoid uncertainty about the jurisdiction of the courts in similar matters. However, assuming each gratitude payment follows a similar routine and might be fitted into the same patterns, namely that it be given either before or after treatment, either voluntarily or not, simply does not reflect the complexity of the social reality of the practice.

Transforming a schematic and often illusory view of social expectation and practice to make legal practice of it might even have the effect of trading-in the anticipated short-term results of restricted transactions for the chance to develop more generalized transactions. Generalized transactions involve more actors and imply more solidarity for others outside the scope of the restricted transactions. They are also the products of longer term legal or policy initiatives with delayed outcomes. It is therefore clear that more sophisticated management and procedural methods might fail because they are less appealing than the hálapénz system already recognized by the Hungarian state and judiciary. Meanwhile, the 'business of being healed' will remain teetering on the edges of the law.

\section{CORRESPONDING AUTHOR}

Petra Burai Max Planck Institute for Social Anthropology, Advokatenweg 36, 06114 Halle (Saale), Germany. E-mail: burai@mail.de

${ }^{67}$ Hungarian health care professionals have already warned that hálapénz might function as 'social capital' regarding the access to medical services. See Zsombor Kovácsy, Hálapénz: nehéz versenyezni a csodaszerrel, $h v g . h u, 24$ May 2012, http://hvg.hu/gazdasag/20120524_kovacsy_zsombor_korrupcio. 